\title{
PERBEDAAN KADAR GLUKOSA DARAH SEWAKTU MENGGUNAKAN SERUM DAN PLASMA EDTA
}

\section{THE DIFFERENCE OF BLOOD GLUCOSE LEVEL USING EDTA SERUM AND PLASMA}

\section{Qurotul Aini Nur Ramadhani , Ardiya Garini, Nurhayati, Sri Hartini Harianja} Jurusan Analis Kesehatan Poltekkes Palembang, Sumatera Selatan, Indonesia (email penulis korespodensi: srihartiniharianja@ poltekkespalembang.ac.id)

\begin{abstract}
ABSTRAK
Latar Belakang: Pemeriksaan gula darah sewaktu digunakan sebagai pemeriksaan penyaring (screening) dan memantau (follow up) pada pasien Diabetes Mellitus. Bahan pemeriksaan kadar glukosa darah dapat menggunakan spesimen darah utuh, serum, dan plasma dengan antikoagulan heparin, EDTA, oksalat, dan fluoride. Perbedaan antara plasma dan serum terjadi karena pada serum tidak terbentuk fibrinogen dan beberapa faktor koagulasi lainnya, sedangkan plasma masih mengandung semua protein dan partikel antikoagulan yang dapat mempengaruhi pemeriksaan. Penelitian ini bertujuan untuk mengetahui perbedaan kadar glukosa darah sewaktu menggunakan serum dan plasma EDTA.

Metode: Jenis penelitian ini observasional analitik, desain potong lintang dan dilakukan di Balai Besar Laboratorium Kesehatan Palembang. Sampel penelitian ini adalah sebanyak 33 sampel,, jumlah sampel ditentukan dengan rumus Lemeshow. Pengambilan sampel menggunakan teknik sampling secara accidental sampling, hingga memenuhi kuota sampel penelitian.

Hasil: Hasil penelitian menunjukkan adanya perbedaan terhadap kadar glukosa darah menggunakan serum dan plasma EDTA dengan p value 0,001 $(<\mathrm{a} 0,05)$ dengan nilai rata-rata pada serum adalah 100,3 mg/dL serta nilai rata-rata pada plasma EDTA adalah 113,5 mg/dL.

Kesimpulan: Nilai rata-rata hasil pemeriksaan kadar glukosa darah menggunakan spesimen serum adalah 91,8 mg/dL sedangkan rata-rata spesimen plasma EDTA adalah 97,2 mg/dL. Hasil uji statistik menyimpulkan ada perbedaan terhadap kadar glukosa menggunakan serum dan plasma EDTA.
\end{abstract}

Kata kunci : Glukosa Darah, Serum, Plasma EDTA

\section{ABSTRACT}

Background:Blood Sugar Sometimes is one of examination parameters of blood glucose levels for patients without fasting permission and can be examined any time. BSS is often being used as a screening test for diabetes disease, it is also one of routine test for monitoring blood glucose levels in diabetic patients. Blood glucose test can use whole blood, serum, and plasma as the specimens. Heparin, EDTA, oxalate, and fluoride can be used as anticoagulants. The difference of BSS levels between plasma and serum occurs because serum does not contain of fibrinogen and other coagulation factors while plasma contains of all the proteins from blood, plasma also contains of EDTA particles that can affect the results. This research aims to determine differences of blood glucose levels using serum and plasma EDTA as specimens.

Methods:It was an analytical research with cross-sectional approach and was conducted in Balai Besar Laboratorium Kesehatan Palembang. The samples were 33 respondents.

Results:The results showed that there was a difference in blood glucose levels using serum and plasma EDTA as specimens with $p$ value in amount of 0.001 (<a 0.05). Serum specimen has an average value in amount of 100,3 $\mathrm{mg} / \mathrm{dL}$ and plasma EDTA has an average value in amount of 113,5 $m g / d L$.

Conclusion:It can be concluded, there are some differences of BSS levels in serum and plasma EDTA. Keywords: Blood Glucose, Serum, Plasma EDTA 


\section{PENDAHULUAN}

Pelayanan laboratorium medik merupakan salah satu hal yang sangat penting untuk pengelolaan pasien dan oleh karena itu harus tersedia fasilitas yang memenuhi kebutuhan pasien dan petugas klinis yang bertanggung jawab dalam pengelolaan pasien. Pelayanan ini mencakup pengaturan untuk permintaan pemeriksaan, persiapan pasien, identifikasi pasien, pengambilan spesimen, transportasi, penyimpanan, pengelolaan dan pemeriksaan spesimen klinik, disertai dengan interpretasinya, laporan hasil dan saran, disamping mempertimbangkan keselamatan dan etika bekerja di laboratorium medik. ${ }^{1}$

Laboratorium klinik telah memusatkan pada metode kontrol kualitas dan program penilaian kualitas yang berhubungan dengan aspek analitik pemeriksaan. Namun, semakin banyak bukti yang terkumpul dalam beberapa dekade terakhir menunjukkan bahwa kualitas di laboratorium klinik tidak dapat dijamin hanya dengan berfokus pada aspek analitik semata. Mutu pelayanan didasari penilaian hasil pelayanan laboratorium secara keseluruhan, dan salah satu titik penting terletak di mutu pemeriksaan atau parameter yang diperiksa. Pemeriksaan akan melalui proses yang kompleks dan panjang sebelum dikeluarkan pemberitahuan oleh laboratorium. Proses yang dilalui dapat dibagi menjadi praanalitik, analitik, dan pasca analitik. Di samping itu dipengaruhi pula oleh bahan, alat, metode, dan hal lain yang terkait. Oleh karena itu perlu strategi guna mencapai mutu pemeriksaan yang diharapkan. ${ }^{2}$

Berdasarkan fakta dalam suatu laboratorium tahap pemeriksaan yang sering diawasi dalam pengendalian mutu hanya tahap analitik dan pasca analitik, sedangkan tahap pra analitik kurang mendapat perhatian. Padahal tahap pra analitik ini dapat memberikan kontribusi sekitar $61 \%$ dari total kesalahan laboratorium, sementara kesalahan analitik 25\%, dan kesalahan pasca analitik $14 \% .^{2,3}$ Tujuan menetapkan standar kualitas laboratorium adalah untuk memastikan keakuratan hasil pemeriksaan, meningkatkan kepercayaan pasien terhadap hasil laboratorium, dan masyarakat dalam menilai kualitas pengujian laboratorium. Semua kegiatan laboratorium dapat mengalami kesalahan, dan penelitian telah menunjukkan bahwa kesalahan di laboratorium dapat terjadi di semua fase prosedur diagnostik. Sebagian besar kesalahan dalam pemeriksaan laboratorium terjadi pada fase praanalitik proses pemeriksaan. ${ }^{4,5}$

Salah satu pemeriksaan laboratorium yang sering dilakukan adalah pemeriksaan glukosa darah. Pemeriksaan glukosa darah yang dilakukan di laboratorium salah satunya adalah glukosa darah sewaktu. Glukosa merupakan kerbohidrat terpenting yang kebanyakan diserap kedalam aliran darah sebagai glukosa dan gula lain diubah menjadi glukosa di hati. Pemeriksaan kadar glukosa darah banyak diusulkan oleh paraklinisi baik untuk tujuan skrining atau pemantauan penyakit Diabetes Militus. Diabetes Melitus adalah penyakit gangguan metabolisme karbohidrat yang ditandai dengan peningkatan kadar gula darah (hiperglikemia) $\geq 200 \mathrm{mg} / \mathrm{dL}$. WHO memprediksikan kenaikan jumlah penderita DM di Indonesia dari 8,4 juta pada tahun 2000 menjadi sekitar 21,3 juta pada tahun 2030. Hal ini menunjukkan adanya peningkatan 2-3 kali jumlah penderita DM pada tahun 2030 di Indonesia. ${ }^{6}$

Akurasi hasil pemeriksaan kadar glukosa darah dipengaruhi oleh banyak faktor, antara lain persiapan pasien yaitu puasa atau tidak, pengumpulan sampel (sampling), preparasi sampel, dan metode pemeriksaan yang digunakan untuk pengukuran kadar glukosa darah. Kadar glukosa darah dapat diperiksa dari sampel darah lengkap (whole blood) yang berasal dari pembuluh darah kapiler atau vena; serum; dan plasma dengan antikoagulan Natrium Fluorida (NaF), Na-oxalate, Na-sitrat, atau Lithiumheparin. ${ }^{2,7}$

Pengukuran glukosa darah dengan spektrofotometer menggunakan prinsip enzimatik yang lebih spesifik untuk glukosa, yaitu perubahan enzimatik glukosa menjadi produk dihitung berdasarkan reaksi perubahan warna (kolorimetri) sebagai reaksi akhir dari serangkaian reaksi kimia. ${ }^{8}$ Pemeriksaan sampel dilakukan dengan menggunakan metode Glukosa Oksidase - Para Aminofenazon (GOD-PAP). ${ }^{9,10}$

Pemeriksaaan kadar glukosa darah dapat menggunakan darah lengkap seperti serum atau plasma. Serum lebih banyak mengandung air daripada darah lengkap sehingga serum berisi lebih banyak glukosa daripada darah lengkap. Serum merupakan bagian cair darah yang bebas dari sel darah dan tanpa fibrinogen karena protein darah sudah berubah menjadi jaring fibrin dan menggumpal bersama sel. Serum diperoleh dari 
spesimen darah yang tidak diberi antikoagulan dan membiarkan darah dalam tabung membeku dalam waktu 15 sampai 30 menit dan kemudian disentifus untuk mengendapkan semua sel-sel darah. Cairan berwarna kuning hasil sentrifugasi itu disebut sebagai serum darah. ${ }^{11}$

Plasma adalah campuran darah dengan antikoagulan. Antikoagulan adalah bahan yang digunakan untuk mencegah pembekuan darah. Antikoagulan yang paling sering digunakan antara lain adalah EDTA, heparin, natrium sitrat, ammonium oxalate, dan kalsium oxalate. ${ }^{9}$ Pemeriksaan kimiawi khususnya pemeriksaan glukosa darah jarang bahkan hampir tidak pernah menggunakan spesimen plasma EDTA. Pemilihan spesimen plasma untuk pemeriksaan glukosa darah diputuskan apabila adanya permintaan glukosa yang cito (segera) dan apabila pemeriksaan glukosa darah tidak diikuti pemeriksaan kimia yang lain dan hanya bersamaan dengan pemeriksaan hematologi rutin, sehingga terkadang cukup menggunakan darah EDTA. $^{12}$

Berdasarkan penelitian sebelumnya didapatkan nilai rata-rata hasil pemeriksaan kadar glukosa darah menggunakan spesimen serum adalah $91,8 \mathrm{mg} / \mathrm{dL}$ sedangkan spesimen plasma EDTA adalah 97,2 mg/dL. ${ }^{13}$ Didukung juga oleh penelitian lain, didapatkan nilai rata-rata hasil pemeriksaan glukosa darah sewaktu menggunakan spesimen serum adalah

\section{METODE}

Jenis penelitian yang digunakan adalah penelitian yang bersifat observasional analitik, desain potong lintang, yang bertujuan membandingkan hasil pemeriksaan kadar glukosa darah sewaktu menggunakan serum dan plasma EDTA. Lokasi penelitian dilakukan di Balai Besar Laboratorium Kesehatan (BBLK) Palembang, dilaksanakan pada bulan Maret-Mei 2019. Spesimen pasien yang diambil sebanyak 33 responden. Jumlah sampel ditentukan dengan rumus Lemeshow: ${ }^{17}$

$$
\mathrm{n}=\frac{Z_{1-a / 2^{2}} \cdot p \cdot q}{d^{2}}
$$

Untuk mengantisipasi jika terdapat kesalahan data atau pemeriksaan maka peneliti menambahkan sebanyak $10 \%$ dari jumlah sampel penelitian, sehingga jumlah sampel penelitian ini sebanyak 33 sampel. Pengambilan sampel menggunakan teknik sampling secara accidental
$139,3 \mathrm{mg} / \mathrm{dL}$ sedangkan menggunakan spesimen plasma EDTA adalah $171 \mathrm{mg} / \mathrm{dL} .{ }^{14}$

Meskipun plasma tidak memiliki eritrosit dan leukosit, namun plasma masih mengandung trombosit. Oleh karena itu trombosit dapat mempengaruhi jumlah glukosa. Di sisi lain, serum bebas dari sel apapun. Serum memiliki kandungan protein yang lebih sedikit jika dibandingkan dengan plasma. Protein terkadang dianggap mengganggu beberapa zat tertentu dalam beberapa pemeriksaan laboratorium karena plasma bereaksi dengan antikoagulan. Meskipun nilai serum dan plasma tidak memiliki perbedaan yang signifikan,sedikit perbedaan ini dapat memengaruhi diagnosis khususnya untuk pasien dengan nilai batas toleransi glukosa terganggu. ${ }^{15}$

Sebagian besar laboratorium menggunakan serum sebagai sampel pemeriksaan kimia termasuk pemeriksaan glukosa. Sebelum dilakukan proses pemeriksaan, sampel serum dibekukan terlebih dahulu sehingga memerlukan waktu yang lebih lama dibandingkan menggunakan sampel plasma. Proses pembekuan tersebut mengkonsumsi glukosa sehingga kadar glukosa menggunakan serum lebih rendah dibandingkan dengan menggunakan plasma. ${ }^{16}$ Berdasarkan latar belakang diatas, peneliti tertarik untuk mengetahui perbedaan kadar glukosa darah sewaktu menggunakan spesimen serum dan plasma EDTA.

sampling, yakni pasien yang kebetulan bertemu dengan peneliti di Balai Besar Laboratorium Kesehatan (BBLK) Palembang hingga memenuhi kuota sampel penelitian. Sampel yang diambil sebagai sampel penelitian adalah pasien yang melakukan pemeriksaan glukosa darah sewaktu.

Pemeriksaan sampel dilakukan dengan menggunakan metode Glukosa Oksidase - Para Aminofenazon (GOD-PAP). Glukosa dioksidasi secara enzimatik menggunakan enzim GOD (glukosa oksidase), membentuk asam glukonik dan $\mathrm{H} 2 \mathrm{O} 2$ kemudian bereaksi dengan fenol dan 4-aminoantipirin dengan enzim peroksidase (POD) sebagai katalisator membentuk quinoeimin. Intensitas warna yang terbentuk sebanding dengan konsentrasi glukosa dalam sampel dan diukur secara fotometri pada panjang gelombang $546 \mathrm{~nm} .^{9,10}$ 
HASIL

Tabel 1. Perbedaan Kadar Glukosa Darah Sewaktu
Menggunakan Serum dan Plasma EDTA

\begin{tabular}{lcccccc}
\hline \multicolumn{7}{c}{ Kadar Glukosa Darah Sewaktu (mg/dL) } \\
\hline \multicolumn{1}{c}{ Variabel } & n & Mean & Min & Max & Std. Deviasi & p value \\
\cline { 1 - 5 } $\begin{array}{l}\text { GlukosaDarah } \\
\text { (Serum) }\end{array}$ & 33 & 100,3 & 71,3 & 146,9 & 19,9 & \\
$\begin{array}{l}\text { Glukosa Darah } \\
\text { (Plasma EDTA) }\end{array}$ & 33 & 113,5 & 74,3 & 172,3 & 22,2 & \\
\hline
\end{tabular}

Kadar glukosa darah sewaktu menggunakan serum memiliki nilai rata-rata sebesar 100,3 mg/dL dengan kadar minimum $71,3 \mathrm{mg} / \mathrm{dL}$ dan kadar maksimum 146,9 mg/dL.Kadar glukosa darah sewaktu menggunakan plasma EDTA memiliki nilai ratarata sebesar 113,5 mg/dL dengan kadar minimun

\section{PEMBAHASAN}

Setelah dilakukan pemeriksaan glukosa darah sewaktu menggunakan serum dan plasma EDTA dan dilakukan analisis data diperoleh hasil yang menunjukkan adanya perbedaan. Dengan analisis data statistik yang telah dilakukan, diketahui rata-rata kadar glukosa darah sewaktu menggunakan serum adalah 100,3 $\mathrm{mg} / \mathrm{dL}$ sedangkan yang menggunakan spesimen plasma EDTA memiliki rata-rata sebesar $113,5 \mathrm{mg} / \mathrm{dL}$.

Hasil penelitian sebelumnya telah dilaporkan bahwa nilai rata-rata hasil pemeriksaan kadar glukosa darah menggunakan spesimen serum adalah $91,8 \mathrm{mg} / \mathrm{dL}$ sedangkan rata-rata spesimen plasma EDTA adalah 97,2 $\mathrm{mg} / \mathrm{dL}$. Penelitian ini juga didukung dari penelitian lainnya, telah dilaporkan nilai rata-rata hasil pemeriksaan glukosa darah sewaktu menggunakan spesimen serum adalah 139,3 $\mathrm{mg} / \mathrm{dL}$ sedangkan menggunakan spesimen plasma EDTA adalah $171 \mathrm{mg} / \mathrm{dL}^{13,14}$ Perbedaan kadar glukosa darah pada spesimen serum dan plasma EDTA terjadi karena pada serum tidak mengandung beberapa faktor koagulasi lainnya, sedangkan plasma masih mengandung faktor koagulasi yang terdapat di dalam darah serta

\section{KESIMPULAN DAN SARAN}

Nilai rata-rata hasil pemeriksaan kadar glukosa darah menggunakan spesimen serum adalah 91,8 $\mathrm{mg} / \mathrm{dL}$ sedangkan rata-rata spesimen
$74,3 \mathrm{mg} / \mathrm{dL}$ dan kadar maksimum 172,3 mg/dL. Hasil uji $t$ dependent yang menghubungkan variabel kadar glukosa darah sewaktu menggunakan serum dan menggunakan plasma EDTA menunjukkan nilai $p$ value 0,001 yang berarti terdapat perbedaan terhadap kedua jenis spesimen tersebut.

mengandung partikel antikoagulan EDTA yang dapat mempengaruhi pemeriksaan. ${ }^{12}$

Meskipun plasma tidak memiliki eritrosit dan leukosit, namun plasma masih mengandung trombosit. Oleh karena itu trombosit dapat mempengaruhi peningkatan jumlah glukosa. Di sisi lain, serum bebas dari sel apapun. Serum memiliki kandungan protein yang lebih sedikit jika dibandingkan dengan plasma. Protein terkadang dianggap mengganggu zat-zat tertentu dalam beberapa pemeriksaan laboratorium. ${ }^{15}$

Sebagian besar laboratorium menggunakan serum sebagai sampel pemeriksaan kimia termasuk pemeriksaan glukosa. Sebelum dilakukan proses pemeriksaan, sampel serum dibekukan terlebih dahulu sehingga memerlukan waktu yang lebih lama dibandingkan menggunakan sampel plasma. ${ }^{16}$

Dari hasil penelitian yang telah dilakukan, dapat disimpulkan bahwa terdapat perbedaan kadar glukosa darah menggunakan spesimen serum dan plasma EDTA. Penggunaan antikoagulan dan kandungan sel darah yang berbeda dapat mempengaruhi hasil pemeriksaan sehingga kadar glukosa pada plasma lebih tinggi daripada serum. ${ }^{19}$

plasma EDTA adalah 97,2 $\mathrm{mg} / \mathrm{dL}$. Hasil uji statistik menyimpulkan adanya perbedaan hasil pemeriksaan kadar glukosa darah sewaktu 
menggunakan serum dan plasma EDTA. Bagi tenaga kerja laboratorium disarankan untuk tetap

\section{UCAPAN TERIMA KASIH}

Terimakasih kepada Kepala Balai Besar Laboratorium Kesehatan (BBLK) atas izin yang

\section{DAFTAR PUSTAKA}

1. Indonesia SN. Laboratorium medikPersyaratan mutu dan kompetensi Medical laboratories - Requirements for quality and competence.

2. Kahar H. Peningkatan Mutu Pemeriksaan di Laboratorium Klinik Rumah Sakit. Indonesian Journal of Clinical Pathology and Medical Laboratory. 2018;12(1):38-40.

3. Yaqin A. Analisis Tahap Pemeriksaan Pra Analitik Sebagai Upaya Peningkatan Mutu Hasil Laboratorium di RS. Muji Rahayu Surabaya Jurnal Sains. 2015;5(10).

4. Livesey JH, Ellis MJ, Evans MJ. Preanalytical requirements. The Clinical Biochemist Reviews. 2008;29(Suppl 1):S11

5. Organization WH. Laboratory quality standards and their implementation. Manila: WHO Regional Office for the Western Pacific; 2011.

6. Amir SM, Wungouw H, Pangemanan D. Kadar Glukosa Darah Sewaktu Pada Pasien Diabetes Melitus Tipe 2 Di Puskesmas Bahu Kota Manado. Jurnal e-Biomedik. 2015;3(1).

7. Julitania E. Perbandingan Stabilitas Kadar Glukosa Darah Dalam Sampel Serum Dengan Plasma Natrium Flourida (Naf): Universitas Kristen Maranatha; 2011.

8. Firgiansyah A. Perbandingan Kadar Glukosa Darah Menggunakan Spektrofotometer dan Glukometer. Skripsi. 2016.

9. Subiyono S, Martsiningsih MA, Gabrela D. Gambaran Kadar Glukosa Darah Metode menggunakan serum sebagi bahan pemeriksaan glukosa darah sewaktu

diberikan bisa melakukan penelitian di BBLK Palembang.

GOD-PAP (Glucose Oxsidase-Peroxidase Aminoantypirin) Sampel Serum dan Plasma EDTA (Ethylen Diamin Terta Acetat). Jurnal Teknologi Laboratorium. 2016;5(1):45-8.

10. Kustiningsih Y, Megawati N, Kartiko JJ, Lutpiatina L. Pengaruh Variasi Suhu Awal Reagen terhadap Kadar Glukosa Darah Metode Enzimatik. Medical Laboratory Technology Journal. 2017;3(1):27-31.

11. Nugraha G. Panduan Pemeriksaan Laboratorium Hematologi Dasar. Trans Info Media, Jakarta. 2015.

12. Apriani A, Umami A. Perbedaan Kadar Glukosa Darah pada Plasma Edta dan Serum dengan Penundaan Pemeriksaan. Jurnal Vokasi Kesehatan. 2018;4(1):19-22.

13. Dimeski G, Yow KS, Brown NN. What is the most suitable blood collection tube for glucose estimation? Annals of clinical biochemistry. 2015;52(2):270-5.

14. Safitri Y. Perbedaan Glukosa Darah Sewaktu Segera dan Ditunda Antara Serum dan Plasma EDTA: Universitas Muhammadiyah Semarang; 2017.

15. Frank EA, Shubha M, D'Souza CJ. Blood glucose determination: plasma or serum? Journal of clinical laboratory analysis. 2012;26(5):317-20.

16. Gupta $S$, Kaur H. Inhibition of glycolysis for glucose estimation in plasma: recent guidelines and their implications. Indian Journal of Clinical Biochemistry. 2014;29(2):262-4.

17. Notoatmodjo S. Metodologi Penelitian Kesehatan. Jakarta: rineka cipta; 2010. 